\title{
Effect of Boron Nitride Addition on the Microstructure and Mechanical Properties of PM Steels
}

\author{
Mehmet Akif ERDEN ${ }^{1}$, Mustafa TÜRKMEN ${ }^{2}$, Hasan KARABULUT ${ }^{1}$, Süleyman GÜNDÜZ ${ }^{3}$ \\ ${ }^{1}$ Karabuk University, TOBB Tech. Sciences Vocational School, 78050 Karabuk. \\ ${ }^{2}$ Kocaeli University, Hereke Sciences Vocational School, Kocaeli. \\ ${ }^{3}$ Karabuk University Technology Faculty, Manufacturing Engineering, Karabuk. \\ makiferden@karabuk.edu.tr, mustafa.turkmen@kocaeli.edu.tr, hasankarabulut@karabuk.edu.tr, \\ Corresponding Author: sgunduz@karabuk.edu.tr
}

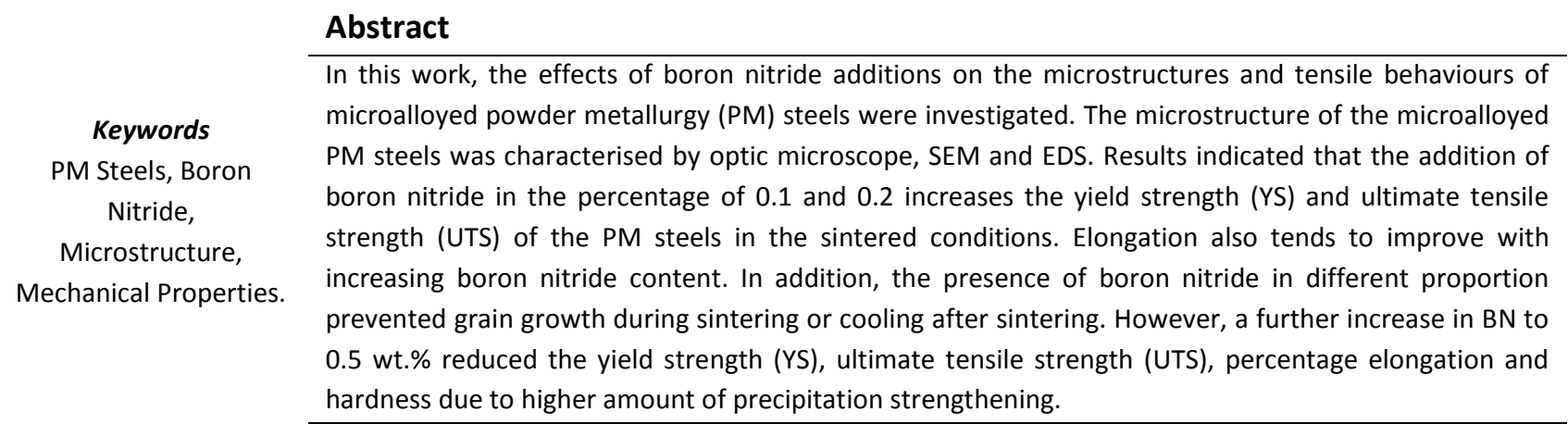

\section{Toz Metal Çeliklerin Mikroyapı ve Mekanik Özelliklerine Bor Nitrürün Etkisi}

Anahtar kelimeler

Toz Metal Çelikler, Bor Nitrür, Mikroyapı, Mekanik Özellikler.

\begin{abstract}
Özet
Bu çalışmada, Mikroalaşımlı Toz metal (TM) çeliklerin mikroyapı ve çekme davranışları üzerine bor nitrür ilavesinin etkileri incelenmiştir. Mikroalaşımlı TM çeliklerin mikroyapıları optik mikroskop, SEM ve EDS analizleri kullanılarak karakterize edilmiştir. Sonuçlar; yüzde 0,1 ve 0,2 oranında bor nitrür ilavesinin TM çeliklerin akma dayanımını (YS) ve çekme mukavemetini (UTS) artırdığını göstermiştir. Ayrıca \% Uzama oranı bor nitrür ilavesinin artmasıyla artma eğilimindedir. Buna ek olarak, farklı oranda bor nitrür varlığı sinterleme sırasında veya sinterleme sonrasında tane büyümesini engellemiştir. Ancak ağırlıkça \% BN oranını 0,5 olduğunda akma dayanımı (YS), çekme dayanımı (UTS), \% uzama ve sertlik değeri çökelme sertleşmesine bağlı olarak azalmıştır.
\end{abstract}

(c) Afyon Kocatepe Üniversitesi

\section{Introduction}

Steels are material groups which can have superior features such as high strength, low ductile-brittle transition temperature and high toughness by the application of various hardening mechanisms and suitable thermodynamic processes (Erden et al. 2014).
Main role of microalloyed elements are to reduce the grain size, prevent recrystallization and contribute to precipitate hardening (Erden et al. 2014; Korchynsky, 2001; Sage, 1992). Boron nitride within the structure of cubic crystal is known to be one of the hardest elements after diamond, and it is also a perfect lubricator in high temperature applications when it exists within the structure of hexagonal crystal cage. However, the only good 
thing with hexagonal boron nitride is not being a lubricator; high thermal conductivity, thermal shock endurance, smooth surface output, refractory characteristics, being inert, low wettability, being a non-poisonous and clean material are its advantages that promoted the use of hexagonal boron nitride (Öztaş, 2012).

Many literatures define powder metallurgy (PM) as the method to manufacture hard-to-produce parts (structures which are small, functional, noncompatible to each other, composite etc.) with high resistance and minimum tolerance (with low diminish) in a more advantageous way compared to other production methods (Schade et al. 2012a; Schade et al. 2012b; Robert, 1984). Today, although most of the microalloyed steels are produced as flat and pipe product, production of microalloyed steels for forging purpose is increasing. Although it is not widely preferred yet, microalloyed steels are also produced by powder metallurgy method today (Erden et al. 2014; Schade et al. 2012b).

The purpose of this study is to investigate the effect of BN amount in the steels produced by PM method on the microstructure and mechanical properties. The change in microstructure and mechanical properties of PM steels are examined when $0.1,0.2$ and 0.5 wt. \% BN are added to the PM steels sintered at $1150{ }^{\circ} \mathrm{C}$.

\section{Material and Method}

In this study, steel samples are produced by PM method with desired compositions and the effects of $\mathrm{BN}$, added in different amounts to the steel, on the microstructure and mechanical properties are investigated. Non-alloyed steel and boron steel are produced by mixing the elements given in Table 1 .

Table 1. Chemical compositions of PM steel specimens.

\begin{tabular}{cccc}
\hline Compound & $\begin{array}{c}\text { Graphite } \\
\text { (wt\%) }\end{array}$ & $\begin{array}{c}\text { BN } \\
\text { (wt\%) }\end{array}$ & $\begin{array}{c}\text { Fe } \\
\text { (wt\%) }\end{array}$ \\
\hline Alloy 1 & 0.45 & - & Balance \\
Alloy 2 & 0.45 & 0.1 & Balance \\
Alloy 3 & 0.45 & 0.2 & Balance \\
Alloy 4 & 0.45 & 0.5 & Balance \\
\hline
\end{tabular}

Iron, graphite and $\mathrm{BN}$ powders were used to produce the steel specimens. The size of graphite, iron and BN powders were $<20, \leq 180$, and $<1 \mu \mathrm{m}$, respectively. These powders were supplied by Aldrich. The purities of graphite, $\mathrm{Fe}$ and $\mathrm{BN}$ are $96.5 \%, 99.9$ and 98\%, respectively. After microstructure characterization in the produced specimens, tensile test is made and the results are compared to each other. Before mixing process, powder was weighed and made ready on digital precision scale with 0.0001 precision in the ratios given in Table 1. Powders are mixed by Turbula T2F mixer for 1 hour without ball and compacted by a using Hidroliksan brand device with 96 tons of press capacity under $700 \mathrm{MPa}$ uniaxial pressure. Tensile test specimens are pressed in a mold prepared in accordance with ASTM (E 8M) powder metal material tensile specimen standards, and turned into a block. Pre-tensile test image of the tensile sample is given in the Figure 1.

$$
10 \mathrm{~mm}
$$

Figure 1. General view of tensile test specimen for Alloy1 sintered at $1150^{\circ} \mathrm{C}$ for $1 \mathrm{~h}$

The pressed specimens are sintered in argon atmosphere at $1150{ }^{\circ} \mathrm{C}$ temperature for 1 hour. Density measurements are made after sintering and pore values are determined. The sintered specimens are made ready for metallographic examination using traditional methods (grinding, polishing and etching). Microstructures of PM steel specimens sintered at $1150^{\circ} \mathrm{C}$ are examined by Nikon Epiphot 200 brand optical microscope with X50-X1000 zoom capacity and Carl Zeiss Ultra Plus Gemini FESEM device. Tensile test is performed by Shimadzu brand tensile device having $50 \mathrm{KN}$ capacity with a crosshead speed of $0.5 \mathrm{~mm} / \mathrm{min}$. Yield strength (0.2\%), tensile strength and percentage elongation values of the specimens are measured. In Shimadzu brand hardness test device, Vickers hardness is measured by applying $0.5 \mathrm{~kg}$ of load. Densities of the specimens are determined according to density determination kit and Archimedes principle. Furthermore, pearlite 
amount of PM steels are calculated by using metallographic point counting method defined by Gladman and Woodhead (1960). In addition; BC, $\mathrm{BN}$ and $\mathrm{BCN}$ precipitates are identified by the help of point and line EDS.

\section{Results and Discussion}

\subsection{Microstructure}

Micrographs of the specimens in Figure 2 shows that, the structure consists of ferrite and pearlite phases in every alloy and there are partially unclosed pores at grain boundaries. Although it is discussed in many references that porosity affects the strength negatively, it is also reported that if pores are very small and have spherical shape, the strength does not decrease (Erden, 2017; Sarıtaş et al. 2007). It is understood from the micrographs that, the grain size decreases as the amount of BN increases in PM steels. In the alloy containing 0.5 wt. \% BN, increased mean grain size is observed. For example; while the average grain size of Alloy 1 is $29.7 \mu \mathrm{m}$, it decreases to $20.37 \mu \mathrm{m}$ and $18.98 \mu \mathrm{m}$ as the amount of BN is increased to 0.1 and $0.2 \mathrm{wt}$. $\%$ respectively, and it is $34.6 \mu \mathrm{m}$ when the amount of $\mathrm{BN}$ is 0.5 wt. \%.
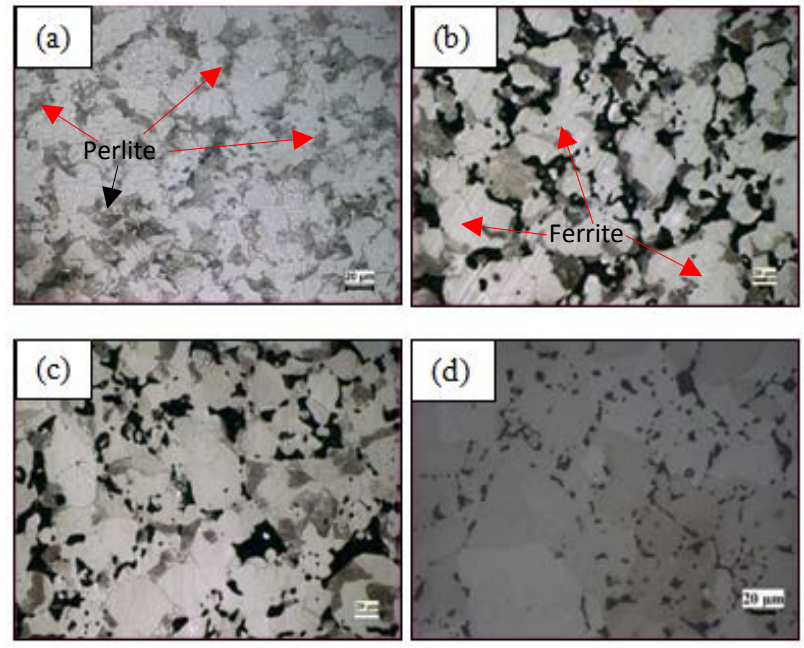

Figure 2. Micrographs of PM steel specimens sintered at 1150 o and containing; (a)0 wt. \% BN , (b)0.1 wt. \% BN , (c) 0.2 wt. \% BN, and (d)0.5 wt. \% (500 x).

Table 2 shows that the grain size decreases as the ratio of $\mathrm{BN}$ increases up to $0.2 \mathrm{wt}$. \% This situation takes place as the $\mathrm{BN}$ and $\mathrm{BC}(\mathrm{N})$ precipitates which are formed during sintering inhibit the growth of austenitic grains (Ollilainen et al. 2003). Microalloying elements inhibit the grain growth during austenitization or sintering with carbides and nitrides they form before. Formation of small precipitates during austenitization inhibits the growth of austenitic grains and leads to formation of small ferrite grains during cooling (Gladman, 1997; Saritas et al. 2007; Ollilainen et al. 2003; Xiang-done et al. 2013; Bakkali et al. 2008).

Table 2. Density, porosity (\%), ferrite-pearlite, average grain size values of PM steel specimens.

\begin{tabular}{cccccc}
\hline Compound & $\begin{array}{c}\text { Relative } \\
\text { density } \\
(\%)\end{array}$ & $\begin{array}{c}\text { Porosity } \\
(\%)\end{array}$ & $\begin{array}{c}\text { Ferrite } \\
(\%)\end{array}$ & $\begin{array}{c}\text { Pearlite } \\
(\%)\end{array}$ & $\begin{array}{c}\text { Average } \\
\text { grain sizes } \\
(\mu \mathrm{m})\end{array}$ \\
\hline Alloy 1 & 92 & 8 & 79.4 & 21.6 & 29.7 \\
Alloy 2 & 91 & 9 & 81.7 & 18.3 & 20.4 \\
Alloy 3 & 91 & 9 & 77.8 & 22.2 & 18.9 \\
Alloy 4 & 90 & 10 & 95 & 17.2 & 34.6 \\
\hline
\end{tabular}

When $\mathrm{BN}$ amount is increased from 0.2 to $0.5 \mathrm{wt} \%$, it is observed that the average grain size increase The reason may be the large BN precipitates formed at grain boundaries (Erden, 2016; Schade et al. 2012a; Schade et al. 2012b). Accumulation of precipitates in grain boundary caused an increase in the amount of pores. Thus, since the formed large precipitates are unable to inhibit the grain growth sufficiently, they lead to a growth in average grain size.

\subsection{Mechanical Properties}

Figure 3 shows the stress - strain diagram of the sintered specimens while Table 3 gives their yield, strength, elongation and hardness values. It can be seen that increasing $\mathrm{BN}$ amount to $0.2 \mathrm{wt}$. \% at $1150{ }^{\circ} \mathrm{C}$ sintering temperature increases the yield and tensile strength, elongation and hardness. Carbide, nitride and carbonitride precipitates, formed by boron element, inhibit grain growth and recrystallization of austenite, and thus provide the material with small grains. Since there is more grain boundary in the small grained structure and 
these grain boundaries block the dislocation movement, strength is improved. Reducing the grain size also contributes to the elongation of material. Besides, the formed precipitates contributed to development of yield strength and tensile strength with various strength developing mechanisms such as precipitate hardening and dispersion hardening (Cuddy and Raley 1983; Ljewellyn and Hudd 1998).

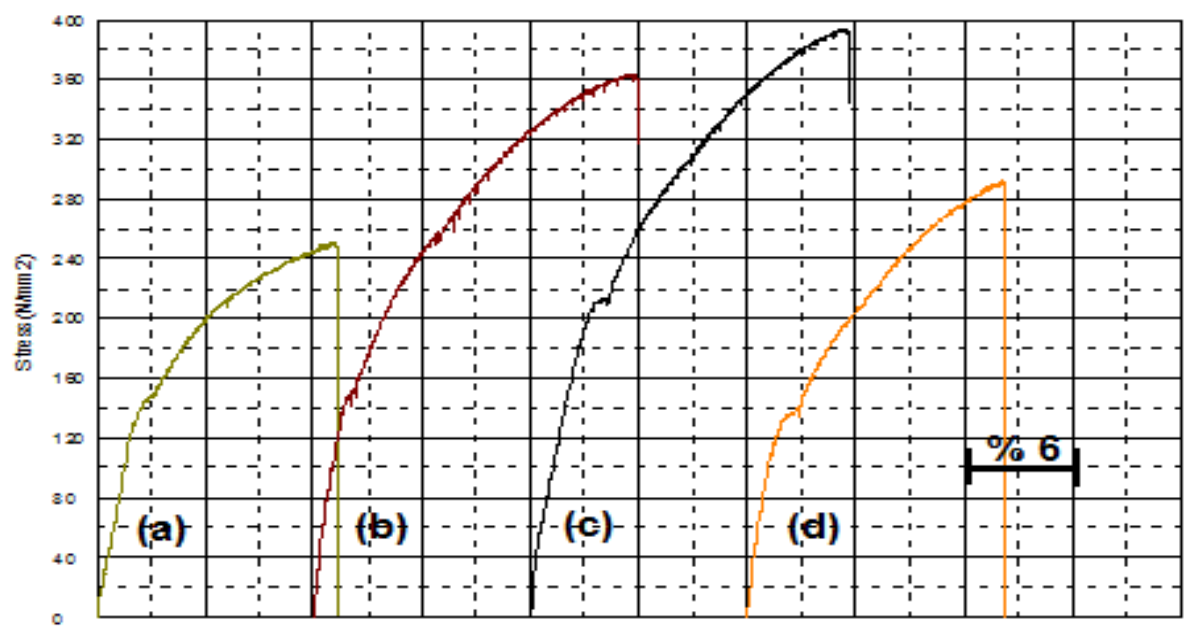

Figure 3. Stress-strain diagrams of PM steels sintered at different temperatures; a) 0 wt. \% BN, b) 0.1 wt. \% BN, c) 0.2 wt. \% BN, d) 0.5 wt. \%.

Table 3. Yield strength, tensile strength, percentage elongation and hardness values of PM steel specimens.

\begin{tabular}{ccccc}
\hline Compound & YS (MPa) & UTS (MPa) & Elongation (\%) & $\begin{array}{c}\text { Hardness } \\
\text { (0.5HV) }\end{array}$ \\
\hline Alloy 1 & 144 & 252 & 13 & 68 \\
Alloy 2 & 153 & 365 & 17 & 110 \\
Alloy 3 & 214 & 396 & 17 & 119 \\
Alloy 4 & 140 & 293 & 14 & 86 \\
\hline
\end{tabular}

It is considered that precipitates such as $B C(N)$ inhibit the growth of grains during sintering and lead to formation of small austenite grains and consequently increase the strength of material. Erden et al. (2014) produced Ti microalloyed steel by PM method in their studies. They performed the sintering process by keeping the steel specimens at $1150^{\circ} \mathrm{C}$ for 60 minutes and determined that, as the Ti ratio increased $(0.1 \%-0.2 \%)$, there is an increase in yield and tensile strength values. They attributed this increase to formation of precipitates such as $\mathrm{TiC}(\mathrm{N})$ during sintering and cooling after sintering. The authors revealed in their study that precipitates such as $\mathrm{TiC}(\mathrm{N})$ prevented the growth of grains during sintering and thus caused formation of small austenite grains and consequently increased the strength of materials. In other studies, (Erden et al. 2014; Schade et al. 2012a; Schade et al. 2012b), it is reported that carbides and nitrides which are formed in microalloyed steels improve hardness and strength. In the same studies, it is stated that solid solution hardening remained in low ratios due to precipitation of carbides and nitrides. Increasing the amount of alloy to $0.5 w t \%$, reduces the yield, tensile, elongation and hardness values. This is due to decrease in strength at high BN levels and formation of $\mathrm{BC}(\mathrm{N})$ precipitates at grain boundaries (Schade et al. 2012a; Schade et al. 2012b). Furthermore, this may be attributed to generally 
decreasing density at $0.5 \%$ alloy addition. Properties such as strength, ductility and conductivity are based on density i.e. porosity and pore structure (Saritas et al. 2007). Furthermore, higher precipitation of $\mathrm{BN}$ in the PM steel causes over-hardening of precipitate and makes the material fragile and decrease its strength.

\subsection{SEM EDS Analysis}

SEM pictures of the 0.1 wt. \% BN specimen given in Figure 4 shows the existence of precipitates with different sizes. Point EDS analysis results indicate that $B C(N)$ precipitates occur since such precipitates contain boron, carbon and nitrogen elements. $\mathrm{Fe}_{3} \mathrm{C}$ precipitates also occur in $\mathrm{PM}$ steel since they include iron and carbon. It is known that these precipitates prevent austenite grain growth and recrystallization (Irvine and Pickering 1963). It can be said that such precipitates prevent austenite grain growth and recrystallization, and increase the strength of material by precipitation hardening (Kostryzhev et al. 2014).

Microalloying elements in the solution slightly effects the recrystallization of austenite. Blocking the grain boundary movement by precipitates is much more effective than dissolved atoms (Korchynsky, 2001).
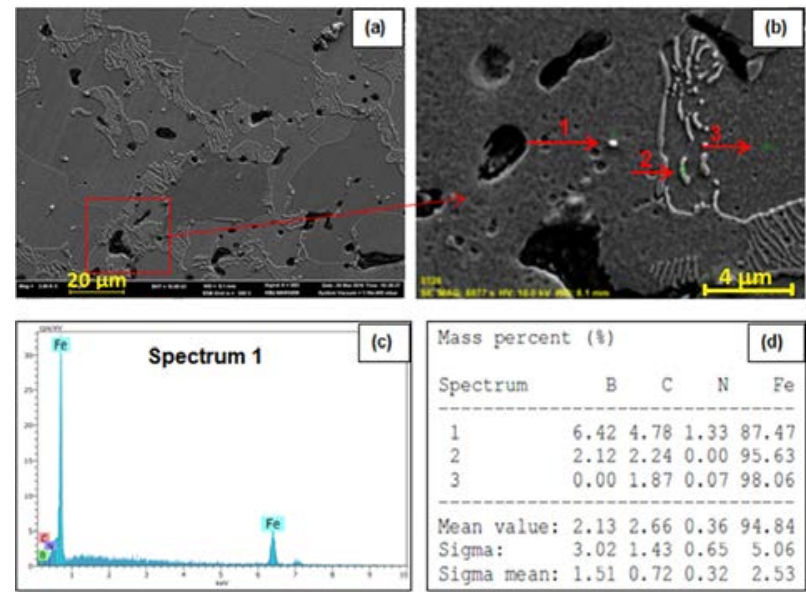

Figure 4. SEM pictures of PM steel specimen sintered at $1150^{\circ} \mathrm{C}$ and contains 0.1 wt. \% BN; (a) X 2000, (b) Point EDSs, (c) Spectrum 1, (d) Point EDS results.

Figure 5 shows the line EDS results of PM steel specimen that is sintered at $1150{ }^{\circ} \mathrm{C}$ and contain
0.1 wt. \% BN, taken from the matrix and precipitates.

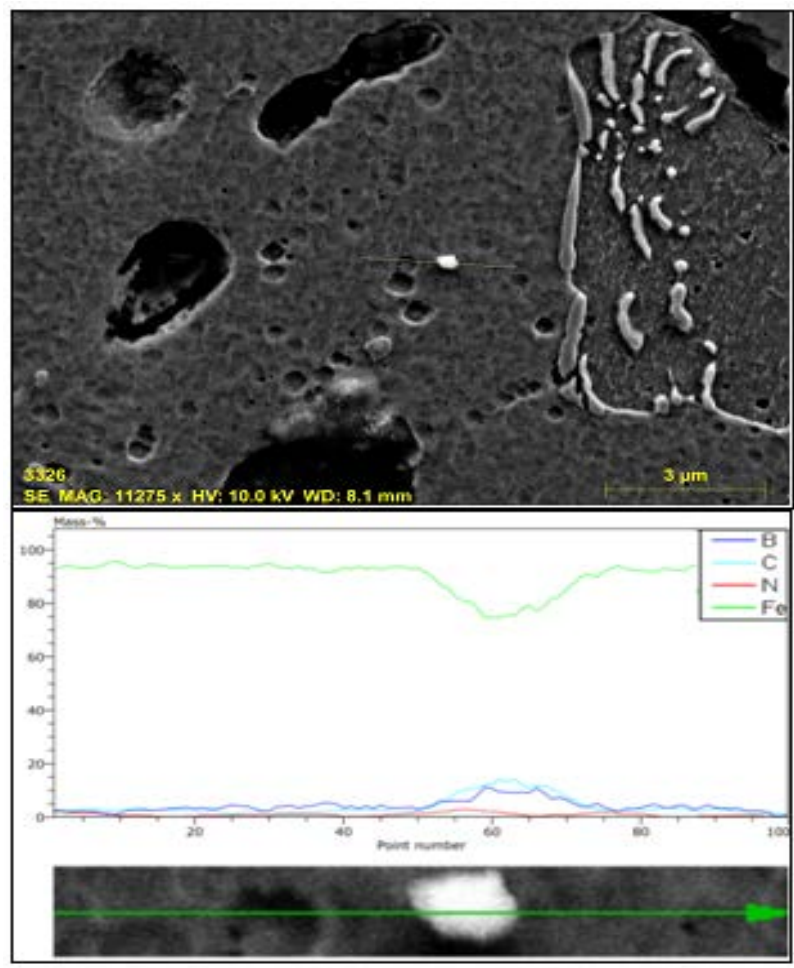

Figure 5. Line EDS results of PM steel specimen that is sintered at $1150{ }^{\circ} \mathrm{C}$ and contains $0.1 \mathrm{wt}$. \% BN, taken from the matrix.

The results show a difference between the type and amount of element along the matrix and the line crossing the precipitate. It is observed that the matrix phase is rich in iron whereas round shape precipitate is rich in boron element. Moreover, there is a sharp increase at the crossing point of the line coming from the matrix with the precipitate. Point and line EDS analyses results obtained from this study reveal that precipitates such as $B C, B N$ and $B C(N)$ are formed in PM steels.

For example, Gündüz et al., studies shows the XRD precipitate peaks of the filter residue of Alloy 3 (Fe0.25C-0.075Nb-0.075Al) (Gündüz at al., 2016). This study, in an alloy containing aluminium and without titanium or niobium, AIN precipitation occurs in the austenitic or ferritic regions. Several investigations report a fine precipitation $(\ll 1 \mu \mathrm{m})$ with a large number density of nitride particles for steels containing between $29.96 \mathrm{mg} / \mathrm{L}$ and 299 mg/Lnitrogen ( Radis and Kozeschnik, 2010). This precipitation is known to have significant effects upon recrystallization and austenite grain growth (Irvine and Pickering, 1963). 
The conclusion indicate a difference between the type and amount of element along the matrix and the line crossing the precipitate such as $\mathrm{BC}, \mathrm{BN}$ and $\mathrm{BC}(\mathrm{N})$ are formed in PM steels.

\section{Conclusion}

BN alloyed PM steel with different amount of BN $(0.1-0.5 \%)$ is produced by cold pressing and sintering in argon atmosphere, and the following results were obtained from this study.

1. Fe matrix PM steels containing $B N$ can be produced by powder metallurgy method. The solid solution hardening and precipitate hardening occurring during the sintering or during the cooling after sintering increased the strength of steel.

2. PM steels with 0.1 and 0.2 wt. $\% B N$ added have smaller grain structure compared to non-alloyed PM steels. This is due to inhibition of grain growth by carbides and nitrides which are formed by the alloy elements. In microstructure examinations of specimens having $0.5 \mathrm{wt}$. \% BN ratio, it is observed that the pearlite ratio is very low $(17.2 \%)$ in their structure. Furthermore, a growth in the grain size was observed. The reason for that may be the formation of $\mathrm{BC}(\mathrm{N})$ precipitates in grain boundaries.

3. In general, as the amount of $\mathrm{BN}$ increased to 0.2 wt. \%, an increase is observed in yield strength, tensile strength, elongation and hardness values of the steels. This is the result of formation of precipitates such as $\mathrm{BC}(\mathrm{N})$ during sintering and during cooling after sintering. Such precipitates prevent the growth of grain during sintering and lead to formation of small austenite grains; and consequently improve the strength of the material.

\section{References}

Bakkali E., Chenaouia A, Dkiouaka R, Elbakkalib L., 2008. Characterization of deformation stability of medium carbon microalloyed steel during hot forging using phenomenological and continoum criteria. Journal of Materials Processing Technology, 140-149.

Cuddy L. C., Raley J. C., 1983. Austenite grain coarsening in microalloyed steels, Metallurgical and Materials Transactions A, 14, 1989-1995.

Erden M. A., Gündüz S., Türkmen M., Karabulut H., 2014. Microstructural characterization and mechanical properties of microalloyed powder metallurgy steels. Materials Science and Engineering A, 616, 201-206.

Erden M. A., 2016. Effect of C Content on Microstructure and Mechanical Properties of $\mathrm{Nb} \mathrm{V}$ Added Microalloyed Steel Produced by Powder Metallurgy Method. European Journal of Science and Technology, 5(9), 44-47.

Erden M. A., 2017. Presleme Basincinin Toz Metalürjisi İle Üretilen Alaşimsiz Çeliklerinin Mikroyapi Mekanik Özellikleri Üzerine Etkisinin Araştirilmasi. Ömer Halisdemir Üniversitesi Mühendislik Bilimleri Dergisi, 6(1), 257-264.

Gladman, T., 1997. The physical metallurgy of microalloyed steels. The Institue of Materials, England, 1, 341.

Gladman, T. and Woodhead, J. H., 1960. The accuracy of point counting in metallographic investigations, Journal of the Iron Steel, 194, 189 (1960).

Gündüz S., Erden M. A., Karabulut H., Türkmen M., 2016. Effect of the addition of niobium and aluminium on the microstructures and mechanical properties of micro-alloyed pm steels. Materials and technology $\mathbf{5 0}$ (5), 641-648.

Irvine K. J, Pickering F. B., 1963. Low carbon steels with ferrite-pearlite structures. The Journal of the Iron and Steel Institute. 201, 944-959.

Kostryzhev AG, Al Shahrani A, Zhu C, Cairney JM, Ringer SP, Killmore CR., 2014. Effect of niobium clustering and precipitation on strength of an $\mathrm{NbTi}$ microalloyed ferritic steel, Materials Science and Engineering: A, 607, 226-235.

Korchynsky M., 2001. A new role for microalloyed steels - adding economic value. Presented at Infacon 9; Quebec City, Canada, 1-6.

Llewellyn D. T., Hudd R. C., 1998. Steels: metallurgy and applications, 3th edn, Reed Educational and Professional Publishing Ltd, Oxford.

Ollilainen, V., Kasprzak W., Hollapa L., 2003. The effect of slicon, vanadium and nitrogen on the microstructure and hardness of air cooled medium 
carbon low alloy steel. Journal of Metarials Processing Technology, 134, 405-412.

Öztaş, E., 2012. Hexagonal Boron Nitride Mold Release Characterization and in availability. Master's Thesis. Gazi University, Ankara, 59.

Radis R., Kozeschnik E. 2010. Kinetics of AIN precipitation in microalloyed steel, Model Simul. Mater. Sci. Eng., 18 (5), 605-611.

Robert, M., 1984. Powder Metallurgy Science. Metal Powder Industry Federation, New Jersey, 1-50.

Sage A. M., 1992. An overview of the use of mikroalloys in hsla steels with particular reference to vanadyum and titanium, processing, properties and applications. Proceedings of the Second International Conference on HSLA Steels, 51-60.

Sarıtaş, S., Türker, M, Durlu, N., 2007. Powder Metallurgy and Particulate Materials Processing, Turkish Powder Metallurgy Association, 2nd ed., Ankara, Turkey, 5-33, 217-230.

Schade C, Murphy T, Lawley A, Doherty R., 2012. Microstrucure and mechanical properties of microalloyed PM steels. International Journal of Powder Metallurgy, 48, 51-59.

Schade, C., Murphy, T., Lawley A., Doherty R., 2012. Microstructure and mechanical properties of PM steels alloyed with silicon and vanadium. International Journal of Powder Metallurgy, 48 (6), 41-48.

Xiang-done H., Xin-ping M, Sheng-xia L., 2013. Effect of annealing temperature on recrystallization behavior of cold rolled Ti-microalloyed steel. Journal of Iron and Steel Research International, 20 (9), 105-110. 